\title{
ЭКОНОМИКА
}

DOI: 10.17805/trudy.2017.2.9

\section{ПРОБЛЕМА ПОВЫШЕНИЯ КВАЛИФИКАЦИИ УПРАВЛЕНЧЕСКОГО ПЕРСОНАЛА В СТРОИТЕЛЬНЫХ ОРГАНИЗАЦИЯХ В РАМКАХ КОНЦЕПЦИИ УПРАВЛЕНИЯ КАЧЕСТВОМ ТРУДА}

\author{
Ю. С. Богданов \\ Московский гуманитарный университет
}

Аннотация: В статье рассматриваются причины и факторы повышения квалификации персонала в строительных организациях, предлагаются мероприятия по повышению квалификации персонала.

Статья подготовлена на основе доклада автора на ХІІІ Международной научной конференции «Высшее образование для ХХІ века» (8-10 декабря 2016 г., Московский гуманитарный университет).

Ключевые слова: строительная отрасль; квалифицированные кадры; управленческий персонал; качество труда

\section{THE PROBLEM OF REFRESHER TRAINING OF MANAGERIAL STAFF IN CONSTRUCTION ORGANIZATIONS IN THE FRAMEWORK OF THE LABOUR QUALITY MANAGEMENT CONCEPT}

\author{
Y. S. Bogdanov \\ Moscow University for the Humanities
}

Abstract: This article discusses the causes and factors of refresher training staff in construction organizations and proposes activities to improve the skills of staff.

The article is based on the author's presentation given at the 13th International Scientific Conference «Higher Education for the 21st Century» (8-10 December 2016, Moscow University for the Humanities). quality

Keywords: construction industry; qualified personnel; managerial personnel; labour

Сегодня строительная отрасль считается одной из самых трудоемких и объемных, принимая во внимание количества участвующих в производственный процесс людей. Кадровая ситуация в этой сфере, как может показаться сначала, является беспроблемной: специалистов строительного профиля разной квалификации и уровня образования хватает, и видимо, выбор необходимой команды для выполнения имеющихся проектов не принесет сложностей. Проблема решается не просто (Управление персоналом ..., Электр. ресурс). 
Причиной данной ситуации является неполное использование кадрового потенциала строительной организации. Возможной причиной является то, что у начинающих специалистов было недостаточно времени, чтобы в необходимом объеме приобрести реальный опыт, и как следствие этого, наблюдается нехватка в квалифицированных кадрах.

Собственно, поэтому, многие строительные организации пытаются найти решение данной задачи путем использования работников предпенсионного и пенсионного возраста, которые имеют четкое представление о своем месте и роли в структуре производственного процесса.

По данным Минэкономразвития РФ, производительность труда отечественных строителей на сегодняшний день в среднем не превышает $25 \%$ от показателей их зарубежных коллег. А конкретнее - 50\% от показателей польских строителей, 40\% - бразильцев, 30\% - от производительности строителей ЮАР (Управление персоналом ..., Электр. ресурс). Причиной этого является малоэффективный HR-менеджмент.

Как свидетельствует практика, основной массе руководителей в принципе не приходилось целенаправленно обучаться основам управления трудовыми ресурсами, потому что не было потребности и времени для обучения этим навыкам. Данная ситуация не лучшим образом влияет на эффективности работы строительной организации.

Наращивание требований к качеству строительства приводит к росту потребности в высококвалифицированных строителях.

Эффективность использования средств производства достигается в первую очередь за счёт эффективного управления персоналом строительных организаций, поэтому необходимо рассмотреть проблему повышения квалификации управленческого персонала строительной организации.

Причинами, подтверждающими необходимость повышения квалификации персонала строительных организаций, сегодня являются:

1. появление новых специальностей и видоизменение старых специальностей;

2. постоянное изменение внешней и внутренней среды строительной организации, которое влечет за собой изменение квалификации персонала;

3. чем большими профессиональными способностями и навыками обладают руководители и специалисты строительной организации, тем выше эффективность управления персоналом и конкурентоспособность данной организации;

4. мотивационная политика строительной организации как фактор профессионального стимулирования персонала;

5. повышение квалификации управленческого персонала в строительных организациях приводит к повышению финансово-экономических 
показателей организации;

6. чем выше квалификация управленческого персонала строительной организации, тем большую пользу можно от него ожидать при выполнении им своих трудовых обязанностей;

7. постоянное повышение квалификации управленческого персонала строительной организации способствует развитию самой организации и выходу на новые рубежи роста;

8. повышение квалификации позволяет управленческому персоналу шагать в ногу со временем и оставаться значимым и востребованным в своей области.

Очевидно, что для повышения качества труда персонала в строительной организации необходим постоянный рост квалификации управленческого персонала. Для этого, по мнению Н. В. Федоровой и О. Ю. Минченковой необходимо наличие следующих условий:

1. чтобы сама организации нуждалась в повышении квалификации своего персонала в текущем и будущем времени;

2. наличие у персонала необходимого образования, возможностей, желания, производственного опыта для повышения собственной квалификации;

3. возможность продвижения персонала вверх по карьерной лестнице (Федорова, Минченкова, 2011).

Факторы, под влиянием которых формируются потребности строительной организации в развитии своего персонала, авторы называют следующие:

-динамика внешней среды;

• развитие техники и технологии, приводящее к появлению новой продукции, услуг и методов производства;

• формирование новой организационной структуры и потребность освоения новых компетенций;

- количество лет, отработанных персоналом на данной должности;

-уровень развития способностей работника, позволяющий ему выполнять трудовые функции определённой степени сложности;

- насколько долго работник остается на своем рабочем месте;

- несоответствие фактических знаний и компетенций персонала быстро развивающейся современной действительности и необходимость повышения квалификации для возможности работы в современных условиях,

• стоимость обучения и его эффективность (там же).

Основными мероприятиями по повышению квалификации управленческого персонала строительной организации могут быть:

- создание структурного подразделения в строительной организации по вопросу необходимости повышения квалификации персонала организации; 
• создание тренировочных программ по управлению строительной организацией;

• создание и изучение учебно-методических материалов по профессиональной переподготовке и повышению квалификации персонала;

- применение учебно-тренировочных программ, разработанных отраслевыми курсами повышения квалификации персонала;

• использование тренировочных методик, созданных в сети Интернета.

Основным вопросом при обучении персонала является его финансирование. Обучение одного работника строительной организации обходится от 3000 рублей в день (Курсы повышения ..., Электр. ресурс). Финансирование осуществляется работодателями и работниками. Средства на обучение берутся из прибыли, что для организации не выгодно.

Альтернативой обучения персонала могут выступать различные технологии стимулирования персонала. В современных условиях для развития мотивации сотрудников предлагается следующая формула накопления средств на субсчет.

$$
\mathrm{BV}=\left[\begin{array}{c}
\mathrm{C}-\frac{T}{T+t} \\
\end{array} \mathrm{C}_{] / 0,02 /} t_{1}\right. \text {, где }
$$

Т - количество лет, которые сотрудник может проработать в этой организации,

$\mathrm{t}$ - количество лет, которые сотрудник уже проработал,

$\mathrm{t}_{1}$ - количество месяцев (например 36), в течении которых будут накапливаться средства на обучение,

0,02 -2\% от ФОТ заложено на обучение персонала,

C - сколько будет потрачено на обучение персонала, руб,

BV - накопление средств на субсчете, руб/мес (например, в течении 36 месяцев).

Данные средства аккумулируются на субсчете. При наступлении сроков обучения деньги снимаются с этого счета. Работник может выбрать какую программу обучения изучать. Доплату за обучение может осуществлять как сам работник, так и руководитель.

В современных условиях с помощью высококвалифицированного управленческого персонала строительной организации возможно достичь высокой эффективности управления персоналом, повышения финансово-экономических показателей деятельности организации, поддерживание конкурентоспособности и развитие самой организации, а также поддержание высокого качества труда всего персонала строительной организации. 


\section{СПИСОК ЛИТЕРАТУРЫ}

Курсы повышения квалификации - строительство обычных и особо опасных объектов [Электронный ресурс] // ПроЭксперт. URL: http://www. sro-licence.ru/attestaciya-i-povyshenie-kvalifikacii/povyshenie-kvalifikatsiistroiteley (дата обращения: 11.12.2016).

Федорова, Н. В., Минченкова, О. Ю. (2011) Управление персоналом организации : учебник. М. : КНОРУС.

Управление персоналом в сфере строительства и производства железобетонных изделий [Электронный ресурс]//BSN.ru.URL: https://www.bsn. ru/partners_articles_200812/upravljenije-pjersonalom-v-sfjerje-stroitjelstvai-proizvodstva-zhjeljezobjetonnykh-izdjelij/ (дата обращения: 11.12.2016).

Дата поступления: 12.12.2016 2.

Богданов Юрий Сергеевич - магистрант кафедры менеджмента Московского гуманитарного университета. Адрес: 111395, Россия, г. Москва, ул. Юности, д. 5. Тел.: +7 (499) 374-58-00. Эл. адрес: bogdanovich11@ yandex.ru. Научный руководитель - д-р. эк. н., проф. О. Ю. Минченкова.

Bogdanov Yuriy Sergeevich, Graduate Student, Department of Management, Moscow University for the Humanities. Postal address: 5, Yunosti St., Moscow, Russian Federation 111395. Tel.: +7 (499) 374-58-00 15-72.E-mail: bogdanovich11@yandex.ru. Scientific Adviser-O. Yu. Minchenkova, Doctor of Economics, Professor.

\section{Для цитирования:}

Богданов Ю. С. Проблема повышения квалификации управленческого персонала в строительных организациях в рамках концепции управления качеством труда [Электронный ресурс] // Научные труды Московского гуманитарного университета. 2017, № 2. URL: http://journals.mosgu.ru/trudy/article/view/455 (дата обращения: дд.мм. гг.). DOI: 10.17805/trudy.2017.2.9 